\title{
Decreased sensitivity to aspirin is associated with altered polyamine metabolism in human prostate cancer cells
}

\author{
Jun $\mathrm{Li}^{1,2} \cdot$ Gary A. Cameron ${ }^{1} \cdot$ Heather M. Wallace ${ }^{1}$
}

Received: 2 September 2015 / Accepted: 20 November 2015 / Published online: 24 December 2015

(C) The Author(s) 2015. This article is published with open access at Springerlink.com

\begin{abstract}
Aspirin is a well-known analgesic, anti-inflammatory and antipyretic drug and is recognised as a chemopreventative agent in cardiovascular disease and, more recently, in colorectal cancer. Although several studies indicate that aspirin is capable of reducing the risk of developing cancers, there is a lack of convincing evidence that aspirin can prevent prostate cancer in man. In this study, aspirin was shown to be an effective inhibitor of the growth of human prostate cancer cells. In order to investigate the link between polyamine catabolism and the effects of aspirin we used a "Tet off" system that induced the activity of spermidine/spermine $N^{1}$-acetyltransferase (SSAT) in human prostate cancer cells (LNCap). Treatment with aspirin was found to decrease induced SSAT activity in these cells. A negative correlation was observed between increased polyamine catabolism via increased SSAT activity and the sensitivity to aspirin. In the presence of increased SSAT activity high amounts of $N^{1}$-acetylspermidine and putrescine were observed. These cells were also found to grow more slowly than the non-induced cells. The results indicate that SSAT and its related polyamine metabolism may play a key role in sensitivity of cancer cells to aspirin and possibly other NSAIDs and this may have implications for the development of novel chemopreventative agents.
\end{abstract}

Handling Editor: E. Agostinelli.

Heather M. Wallace

h.m.wallace@abdn.ac.uk

1 Division of Applied Medicine, School of Medicine and Dentistry and School of Medical Sciences, University of Aberdeen, Aberdeen, UK

2 Present Address: Cancer Research Centre, Western General Hospital, University of Edinburgh, Edinburgh, UK
Keywords Polyamines $\cdot$ SSAT $\cdot$ Prostate cancer

\section{Introduction}

Prostate cancer is the second most frequently diagnosed cancer in men and the fifth most common cancer overall worldwide (Globocan 2008). Advancing age, race, geographical distribution, diet and family history are the important risk factors contributing to the incidence of this disease (Isaacs et al. 2002). Prostate cancer is mainly a disease of ageing as most cases occur above the age of 60 , indicating a slow development of the disease over the years (Khandrika et al. 2009). Men with non-clinical defined prostate cancer at the age of 80 or 90 would be likely to die of other causes rather than the disease itself (Lin and Nelson 2003). Therefore, a strategy of chemoprevention to prevent or delay development of the disease in younger men would be useful and could reduce the prevalence of clinically manifest prostate cancer. LNCaP is an androgendependent prostate carcinoma cell line that is considered to represent early stage of prostate cancer development and mimics the disease progression (Dozmorov et al. 2009). Thus, this cell line model is more representative than the other prostate cancer cell lines such as PC-3 and DU-145 to study the effect of aspirin in cancer chemoprevention.

Aspirin use is known to be associated with the chemoprevention of colorectal cancer. However, there is a lack of convincing clinical association between aspirin use and a reduction of prostate cancer incidence, although some studies imply that aspirin use might be inversely related to the risks of developing prostate cancer (Mahmud et al. 2004; Rothwell et al. 2011; Bosetti et al. 2009). In vitro studies reported that NSAIDs could inhibit proliferation of prostate cancer cells such that a selective COX-2 inhibitor, NS398 
or celecoxib, and can result in apoptosis (Liu et al. 1998; Hsu et al. 2000). The underlying mechanisms are thought to be related to the inhibition of cyclooxygenases (COX-1 and -2) and decreased production of prostaglandins (Michael et al. 2012). However, it has been suggested that mechanisms that are not dependent on COX inhibition such as inhibition of NF- $\mathrm{KB}$ (Babbar et al. 2006) and induction of polyamine catabolism (Hughes et al. 2012) may also be involved in this process.

Polyamines (putrescine, spermidine and spermine) are small polycations present in all mammalian cells. They are indispensable growth factors stimulating cell proliferation through binding to DNA, RNA and proteins (Wallace 2000; Wallace et al. 2003; Criss 2003). This has made the polyamine pathway an attractive target for growth inhibition and for the development of potential novel anticancer strategies. Spermidine/spermine $N^{1}$-acetyltransferase (SSAT) is the first enzyme in polyamine catabolism. It acetylates spermidine and spermine to form $N^{1}$-acetylspermidine and $N^{1}$-acetylspermine, respectively. Acetylation by SSAT is a prerequisite for the export of intracellular polyamines when excess polyamines are present (Shappell et al. 1993). The majority of $N^{1}$-acetylated polyamines produced by SSAT are exported out of the cell via the polyamine export system, thus maintaining intracellular polyamine concentrations within predefined limits to maintain optimal rates of cell growth (Pegg 2009).

The SSAT gene is highly inducible by many stimuli including cell stress, toxins, anticancer drugs and polyamine analogues, e.g., $N^{1}, N^{11}$-diethylnorspermine (Mandal et al. 2013). An increase in SSAT activity can lead to an inhibition of cell growth in a number of tumour cell lines (Mandal et al. 2013; Vujcic et al. 2000; Kramer et al. 2008). This is mainly thought to be as a result of a disruption to the cellular polyamine metabolism. Aspirin, as a growth inhibitor in cancer cells, is recognised as an inducer of SSAT, which is associated with the binding of NF- $\mathrm{KB}$ on the Sat1 gene (Babbar et al. 2006).

The aim of this study was to investigate whether there is an association between SSAT activity, the subsequently altered polyamine metabolism and the sensitivity of prostate cancer cells to aspirin. Our hypothesis was that increased SSAT activity will enhance the growth inhibitory effects of the drugs.

\section{Materials and methods}

\section{Chemicals and labware}

Aspirin, acetyl-coenzyme A, aminoguanidine hemi-sulphate, bovine serum albumin, tetracycline hydrochloride, trypan blue, dansyl chloride, 3-(4,5-dimethylthiazolyl)2,5-diphenyl-tetrazolium bromide (MTT) and 1,7-diaminoheptane were purchased from Sigma-Aldrich, Co. (Poole, UK). Copper sulphate and toluene were purchased from Sigma-Aldrich, Co. (Gillingham, UK). Folin's-Ciocalteau reagent was purchased from BDH Chemical Co. (Poole, UK). Dithiothreitol was purchased from Sigma Chemical Co. (St. Louis, USA). Geneticin (G418) hygromycin B, RPMI1640 medium, trypsin, $60 \mathrm{~mm}$ diameter cell culture dishes and $T 75 \mathrm{~cm}^{2}$ cell culture flasks were purchased from PAA Laboratories Ltd. (Yeovil, UK). Perchloric acid and methanol were purchased from VWR International Ltd. (Lutterworth, UK). Potassium sodium tartrate was purchased from Sigma-Aldrich Co. (Spain). Scintillation cocktail was purchased from GE Healthcare (Buckinghamshire, UK). Tris base was purchased from Melford Laboratories Ltd. (Ipswich, UK). Acetone was purchased from Fisher Scientific Ltd. (Loughborough, UK). L-Proline was purchased from Sigma-Aldrich Co. (China). $N^{1}$-Acetylspermidine hydrochloride and $N^{1}$-acetylspermine trihydrochloride were purchased from Fluka (Switzerland). Sodium carbonate decahydrate was purchased from Sigma-Aldrich, Co. (Germany). Foetal bovine serum (tetracycline free) was purchased from Labtech International Ltd. (Uckfield, UK). $\left[{ }^{3} \mathrm{H}\right]$ acetyl-coenzyme A and $\left[{ }^{14} \mathrm{C}\right]$ L-ornithine were purchased from PerkinElmer (Cambridge, UK).

\section{Cell culture}

The SSAT human cDNA transfected LNCaP cell line was a kind gift from Drs Carl Porter and Debora Kramer (Roswell Park Memorial Institute, Buffalo, USA). This cell line was genetically transfected with SSAT human cDNA using the tetracycline-off (Tet-off) Advanced Inducible Gene Expression System. Cells were cultured routinely in the presence of tetracycline (Tet) that inhibited the exogenous SSAT expression, producing basal SSAT enzymatic activity $(2.13 \pm 0.51 \mathrm{pmol} / \mathrm{min} / \mathrm{mg}$ protein $)$ represented as SSAT $^{-}$cells. In the absence of Tet, the SAT1 gene transcription was overexpressed leading to a significant increase in SSAT enzymatic activity $(52.38 \pm 3.88 \mathrm{pmol} /$ $\mathrm{min} / \mathrm{mg}$ protein) represented as $\mathrm{SSAT}^{+}$cells. Culture medium: RPMI1640 with L-glutamine $+50 \mathrm{mg} / \mathrm{ml}$ $\mathrm{G} 418+150 \mu \mathrm{g} / \mathrm{ml}$ hygromycin B $+1 \mathrm{mM}$ aminoguanidine $+10 \%(\mathrm{v} / \mathrm{v})$ Tet free Foetal Bovine Serum $+0.4 \mu \mathrm{g} /$ $\mathrm{ml}$ Tet (Tet-free culture medium was the same but without Tet supplementation). The medium was replaced every two days due to a short half-life of Tet in culture $(<48 \mathrm{~h})$. LNCap cell seeding density was $2.4 \times 10^{4} / \mathrm{cm}^{2}$. The cells were cultured routinely in a $775 \mathrm{~cm}^{2}$ culture flask containing $15 \mathrm{ml}$ culture medium at $37^{\circ} \mathrm{C}$ in a humidified incubator supplemented with $5 \% \mathrm{CO}_{2}$. 


\section{Trypan blue cell exclusion assay}

The cells were plated in a $60 \mathrm{~mm}$ diameter cell culture dish in duplicate and incubated for $48 \mathrm{~h}$ prior to treatment with aspirin ( $2 \mathrm{M}$ stock in ethanol). The cells were trypsinized and stained with trypan blue, and viable cell numbers were counted under a Zeiss light microscope.

\section{SSAT enzyme activity assay}

The method of measuring SSAT activity was described by Wallace and Evans (1998). Cells were lysed in $0.5 \mathrm{ml}$ hypotonic lysis buffer $\left[10 \mathrm{mM}\right.$ Tris $\left(\mathrm{pH} 7.2\right.$ at $4{ }^{\circ} \mathrm{C}$ ), $1 \mathrm{mM}$ EDTA and $2.5 \mathrm{mM}$ dithiothreitol]. $40 \mu \mathrm{l}$ of the cell lysate was used for protein quantification (Lowry assay). The remaining cell homogenate was ultra-centrifuged at 100,000 gav for $70 \mathrm{~min}$ at $4{ }^{\circ} \mathrm{C}$ to separate cytosol. $60 \mu \mathrm{l}$ of the cytosol was assayed in duplicate in addition of $10 \mu \mathrm{l}$ of $30 \mathrm{mM}$ spermidine and $10 \mu \mathrm{l}$ of $1 \mathrm{M}$ Tris $\mathrm{HCl}(\mathrm{pH} 7.8$ at $37{ }^{\circ} \mathrm{C}$ ), and incubated at $37{ }^{\circ} \mathrm{C}$ for $2 \mathrm{~min}$. The reaction was started in ten second cycles on the addition of $10 \mu 1$ of $250 \mu \mathrm{M}$ acetyl $\mathrm{CoA}$ and $10 \mu \mathrm{l}$ of $0.33 \mu \mathrm{Ci}$ of $\left[{ }^{3} \mathrm{H}\right]$-acetyl CoA. All the samples were incubated for $10 \mathrm{~min}$ at $37{ }^{\circ} \mathrm{C}$, and then $20 \mu \mathrm{l}$ of $1 \mathrm{M}$ hydroxylamine was assayed stop the reaction. Samples were boiled for 3 min to precipitate any remaining protein, and centrifuged at $1600 \mathrm{~g}$ for $3 \mathrm{~min}$ to pellet the protein. $30 \mu \mathrm{l}$ of the supernatant was spotted in duplicate onto a Whatman P81 cellulose phosphate-loaded disc. The discs were dried and washed once in tap water, three times in distilled water for $2 \mathrm{~min}$, and finally once in $100 \%$ ethanol to remove unbound $\left[{ }^{3} \mathrm{H}\right]$-acetyl CoA. The discs were dried again. Each dried paper disc was transferred into a scintillation vial with an addition of $4 \mathrm{ml}$ biodegradable scintillation fluid. The radioactivity of the samples was determined via a tritium protocol by using a Packard 1900 CA Tris carb scintillation analyser. Results were shown as pmol $N^{1}$-acetylspermidine formed/min/mg protein.

\section{ODC enzyme activity assay}

ODC activity can be determined by measuring the amount of radiolabelled carbon dioxide $\left(\left[{ }^{14}\right] \mathrm{CO}_{2}\right)$ produced during the decarboxylation of $\mathrm{L}-\left[1-{ }^{14} \mathrm{C}\right]$ ornithine to form putrescine (Tabib 1998). The reaction was carried out in a sealed glass tube and $\mathrm{CO}_{2}$ was trapped in benzethonium hydroxide solution. The cell pellet was lysed in $0.5 \mathrm{ml}$ homogenising buffer $(10 \mathrm{mM}$ Tris- $\mathrm{HCl}, 2.5 \mathrm{mM}$ dithiothreitol and $0.1 \mathrm{mM}$ EDTA). $40 \mu \mathrm{l}$ of the homogenate was taken for protein content determination (Lowry assay). The cell homogenate was centrifuged at a speed of $35,000 \mathrm{~g}$ at $4{ }^{\circ} \mathrm{C}$ for $30 \mathrm{~min}$. A stock assay mixes in which $50 \mu \mathrm{l}$ aliquot was dispensed into each reaction tube. The mixture was composed of $12.5 \mu \mathrm{l}$ of $1 \mathrm{M}$ Tris- $\mathrm{HCl}\left(\mathrm{pH} 7.5\right.$ at $37{ }^{\circ} \mathrm{C}$ ), $5 \mu \mathrm{l}$ of $2 \mathrm{mM}$ pyridoxal $5^{\prime}$-phosphate, $2.5 \mu \mathrm{l}$ of $250 \mathrm{mM}$ dithiothreitol, $5 \mu \mathrm{l}$ of $20 \mathrm{mM}$ L-ornithine, and $2.5 \mu \mathrm{l}$ of L-[1${ }^{14} \mathrm{C}$ ] ornithine, and $22.5 \mu \mathrm{l}$ of deionised water. To each prechilled tube, $100 \mu \mathrm{l}$ of the homogenising buffer and $50 \mu \mathrm{l}$ aliquot of the assay mixture stock were added. $100 \mu$ l benzethonium hydroxide was placed in each well which had been inserted into the rubber stopper for absorbing released $\left[{ }^{14}\right] \mathrm{CO}_{2}$. Finally, $100 \mu \mathrm{l}$ of the enzyme extract was added to the reaction tube, making a final volume of $250 \mu \mathrm{l} .100 \mu \mathrm{l}$ of the homogenising buffer instead of the enzyme extract was used as the blanks. All tubes were sealed tightly with the rubber stoppers with inserted wells and incubated in a shaking water bath for $1 \mathrm{~h}$ at $37^{\circ} \mathrm{C} .0 .3 \mathrm{ml}$ of $2 \mathrm{M}$ perchloric acid was assayed per tube to stop the reaction and the tubes were further incubated for $45 \mathrm{~min}$. All the wells from the tubes were transferred into scintillation vials in addition of $4 \mathrm{ml}$ scintillation fluid. The vials were left in dark overnight. Each sample was counted as disintegrations per minute (dpm) for 10 min using a $\left[{ }^{14} \mathrm{C}\right]$ protocol by a Canberra Packard 1900A liquid scintillation analyser. Results were calculated as $\mathrm{pmol}{ }^{14} \mathrm{CO}_{2}$ generated/h/mg protein.

\section{Measurement of intracellular polyamine content by LC-MS-MS}

Perchloric acid-extracted intracellular polyamines were quantified using a Thermo Surveyor-TSQ Quantum system (Thermo Scientific, Hemel Hempstead, UK) following derivatization with dansyl chloride in a total run time of $6 \mathrm{~min}$. The derivatised polyamines were resolved using a $5 \mu \mathrm{l}$ Hichrom HIRPB column $(150 \times 2.1 \mathrm{~mm})$ and guard cartridge (Hichrom Ltd. Reading, UK) with a mobile phase consisting of water/methanol/formic acid (10/90/0.02). The flow rate was $200 \mu \mathrm{l} / \mathrm{min}$, the column was maintained at $40{ }^{\circ} \mathrm{C}$ and the autosampler at $4{ }^{\circ} \mathrm{C}$ with $2 \mu \mathrm{l}$ injected onto the chromatograph. The column eluent was diverted to waste for the first 2 min of the run. The TSQ Quantum was equipped with an electrospray (ESI) ionisation source and operated in positive ion mode using the following ionisation conditions with a peak width of 0.7 for both Q1 and Q3: spray voltage $4000 \mathrm{~V}$, sheath gas (nitrogen) 30 (arbitrary units), auxiliary gas 0 (arbitrary units), capillary temperature $375{ }^{\circ} \mathrm{C}$ and skimmer offset $-12 \mathrm{~V}$. Detection was performed in single reaction monitoring (SRM) scan mode with the following SRM transitions and collision energies at a collision gas (Argon) pressure of 1.5 mTorr: putrescine 555.2-170@31 V, 1,7-diaminoheptane (internal standard) 597.2-170@37 V, $N^{1}$-acetylspermidine 654.2-100@26 V, $N^{8}$-acetylspermidine 654.2-362@26 V, $N^{1}, N^{12}$-diacetylspermine 753.2100@31 V, spermidine 845.2-360@34 V, $N^{1}$-acetylspermine 944.5-100@31 V and spermine 1135.3-360@45 V. The resolution setting for both Q1 and Q3 was 0.2 and each SRM 
scan time was $0.1 \mathrm{~s}$. Thermo Xcalibur software (v. 2.0.7 SP1) was used for peak integration and quantification was achieved by comparing the peak area ratios with those from calibration curves constructed from the pure standards in the concentration range $0.016-1.0 \mathrm{nmol}$.

\section{Total cellular protein determination (Lowry assay)}

Total cellular protein content was determined by a modified method from Lowry et al. (1951) using a 96-well plate. A standard linear curve was prepared in the range of 0-250 $\mu \mathrm{g} / \mathrm{ml}$ using $0.5 \mathrm{mg} / \mathrm{ml}$ bovine serum albumin (BSA) and $0.3 \mathrm{M} \mathrm{NaOH}$. Samples were exposed to $0.13 \mathrm{M}$ FolinCiocalteau reagent for $20 \mathrm{~min}$ in the dark and absorbance was measured at a wavelength of $690 \mathrm{~nm}$. Total cellular protein content was expressed as $\mathrm{mg} /$ culture.

\section{Polyamine export measurement}

Polyamine efflux can be measured by quantifying total $\left[{ }^{3} \mathrm{H}\right]$ labelled polyamines in the extracellular media after prelabelling cells with $\left[{ }^{3} \mathrm{H}\right]$ putrescine (Wallace and Mackarel 1998). The cells were incubated in the addition of $18.5 \mathrm{kBq} /$ $\mathrm{ml}$ of $\left[{ }^{3} \mathrm{H}\right]$-putrescine for $36 \mathrm{~h}$. After replacing with fresh medium and further $12 \mathrm{~h}$ incubation, the cells were harvested in a time course. The medium volume was recorded and centrifuged. $1 \mathrm{ml}$ of the medium supernatant was mixed with $0.25 \mathrm{ml}$ of $1 \mathrm{M} \mathrm{HClO}_{4}$, and the cell pellet was re-suspended in $1 \mathrm{ml}$ of $0.2 \mathrm{M} \mathrm{HClO}_{4}$ for polyamine extraction. $50 \mu \mathrm{l}$ of the supernatant from the cell extract plus $450 \mu \mathrm{l}$ of RPMI 1640 medium, and $450 \mu \mathrm{l}$ from the $\left[{ }^{3} \mathrm{H}\right]$ medium extract plus $50 \mu \mathrm{l}$ of $0.2 \mathrm{M} \mathrm{HClO}_{4}$ were analysed by a Canberra Packard 1900A liquid scintillation analyser. The total radioactivity [disintegrations per minute $(\mathrm{dpm})]$ was the sum of the cell (intracellular) and the medium (extracellular) fraction radioactivity. The extracellular radioactivity was expressed as a percentage of the total radioactivity.

\section{Statistical method}

Statistical analysis was performed using GraphPad software Prism 5 (GraphPad Software, Inc., 2236 Avenida de la Playa, La Jolla, CA 92037, USA). Results were analysed by two-way analysis of variance (ANOVA) with Bonferroni post-tests. A $p$ value of less than 0.05 was considered as statistically significant. There are no ethical issues with this manuscript as all work was carried out on cell lines.

\section{Results}

Initial studies investigated the efficacy of the "Tet-off" system and determined SSAT enzyme activity in both

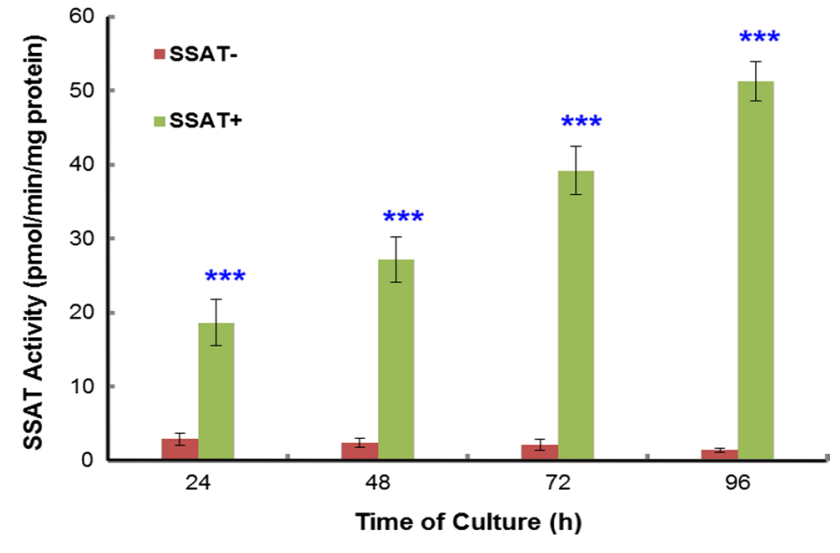

Fig. 1 SSAT activity in induced and non-induced LNG53 cells. Cells were seeded at a density of $2.4 \times 10^{4} / \mathrm{cm}^{2}$ in $60 \mathrm{~mm}$ cell culture dish in duplicate. Cells were harvested at $24 \mathrm{~h}$ intervals. Media were replaced with fresh media at $24,72 \mathrm{~h}$. Results shown are mean $\pm \operatorname{SEM}$ ( $n=3$, with 4 replicate per experiment). Statistical analysis was performed by two-way ANOVA with Bonferroni posttest. $* * * p<0.001$

$\mathrm{SSAT}^{-}$and $\mathrm{SSAT}^{+}$cells over time. Activity in $\mathrm{SSAT}^{+}$ cells was about 10-18 fold higher than that in $\mathrm{SSAT}^{-}$cells and increased in a time-dependent manner (Fig. 1). SSAT activity in $\mathrm{SSAT}^{-}$cells remained low throughout (Fig. 1). Thereby, confirming that SSAT activity can be altered by using the "Tet-off" system. Western blot and qPCR confirmed increased protein and mRNA in the $\mathrm{SSAT}^{+}$cells (results not shown). The activity in the $\mathrm{SSAT}^{-}$cells was lower than the equivalent wild type LNCaP cells (results not shown). Increased SSAT expression altered the growth of the cells with increased SSAT activity inhibiting

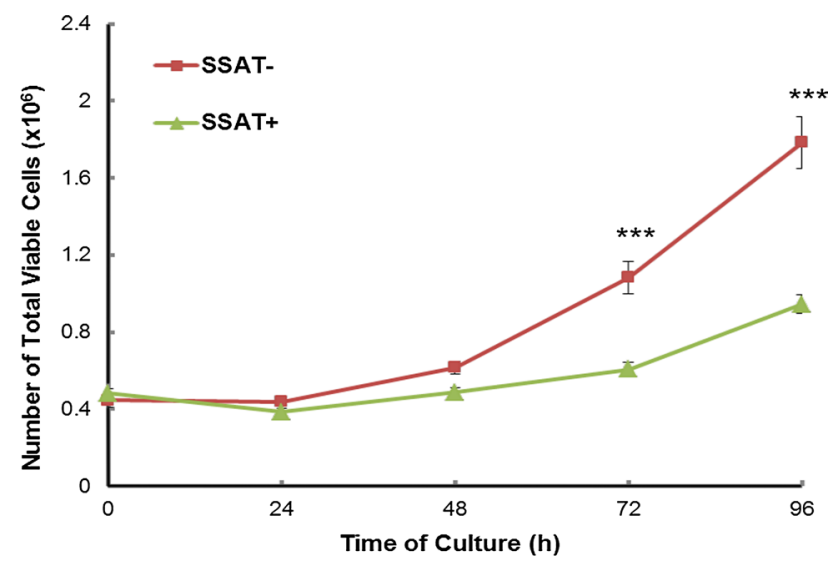

Fig. 2 Growth of induced $\left(\mathrm{SSAT}^{+}\right)$and non-induced $\left(\mathrm{SSAT}^{-}\right)$cells. Cells were seeded at a density of $2.4 \times 10^{4} / \mathrm{cm}^{2}$ in $60 \mathrm{~mm}$ cell culture dish in duplicate. Cells were harvested at $24 \mathrm{~h}$ intervals and viable cell numbers counted using Trypan blue exclusion assay. Results shown are mean $\pm \operatorname{SEM}(n=4-16$, with 2 replicate per experiment). Statistical analysis was performed by two-way ANOVA using Prism 5. ***p $p<0.001$ 
cell growth (Fig. 2) and prolonging the generation time (Table 1). The activity of the main polyamine biosynthetic enzyme, ornithine decarboxylase (ODC), was also increased dramatically in $\mathrm{SSAT}^{+}$cells (Table 2A).

Analysis of the intracellular polyamine concentrations in response to altered SSAT activity showed marked increases in $N^{1}$-acetylpolyamines and putrescine in $\mathrm{SSAT}^{+}$cells (53-, 16-, and fivefold increases in $N^{1}$-acetylspermidine, $N^{1}$-acetylspermine, and putrescine respectively). Spermine decreased by $57 \%$ but there was little change in spermidine in $\mathrm{SSAT}^{+}$cells. Overall, there was little difference in the total polyamine content (Table 3). The alterations of intracellular polyamine concentrations were consistent with the altered enzyme activity of SSAT and ODC in these cells.

Table 1 Generation time in SSAT ${ }^{-}$and SSAT ${ }^{+}$cells

\begin{tabular}{llcc}
\hline Time of culture & $48 \mathrm{~h}$ & $72 \mathrm{~h}$ & $96 \mathrm{~h}$ \\
Cell type & \multicolumn{1}{c}{ Generation time (h) } & \\
$\mathrm{SSAT}^{-}$ & 39 & 34 & 34 \\
$\mathrm{SSAT}^{+}$ & 50 & 62 & 51 \\
\hline
\end{tabular}

Cells were seeded at a density of $2.4 \times 10^{4} / \mathrm{cm}^{2}$ in $60 \mathrm{~mm}$ cell culture dish in duplicate. Viable cell numbers were counted using Trypan blue exclusion assay. Mean of the viable cell numbers were used to calculate generation time $(\mathrm{Gt})$. Results were calculated by the equation $\mathrm{Gt}=\log 2 \times \Delta \mathrm{t} / \log \left(N / N_{0}\right)$ related to the total viable cell numbers at $24 \mathrm{~h}$. $\Delta t$ change in time (h), $N$ final cell number, $N_{0}$ initial cell number
Our hypothesis was that the cells with altered SSAT activity would respond differently to aspirin. However, when the apparent $\mathrm{IC}_{50}$ of aspirin, a chemopreventative agent, was determined by MTT assay the values were found to be similar $\left(2.83 \pm 0.09\right.$ and $2.64 \pm 0.16$ in SSAT $^{-}$ and $\mathrm{SSAT}^{+}$respectively. $2 \mathrm{mM}$ aspirin was therefore chosen for the remainder of the study.

The effect of aspirin on cell growth was investigated. Increased SSAT activity decreased the sensitivity of the cells to aspirin, at least, initially. In the treated cells, the growth of SSAT ${ }^{-}$cells was inhibited by $25 \%(24 \mathrm{~h})$ and $58 \%(48 \mathrm{~h})$, however, in $\mathrm{SSAT}^{+}$cells the growth inhibition was $2 \%(24 \mathrm{~h})$ and $28 \%(48 \mathrm{~h})$, respectively (Table 4$)$. This indicates that the cells with higher SSAT activity are resistant to aspirin treatment at an early stage. Aspirin can inhibit cell proliferation by depleting total intracellular polyamines in vitro (Wallace and Hughes 2006). As shown in Table 5, total polyamines were decreased by aspirin, which corresponded to the results of growth inhibition. These differences in growth inhibition were no longer obvious by 72 and $96 \mathrm{~h}$ (Table 4). This is because the SSAT activity in $\mathrm{SSAT}^{+}$cells was decreased (from more than 40 to less than 10) by aspirin to a level similar to that in $\mathrm{SSAT}^{-}$cells at 72 and $96 \mathrm{~h}$. As a result, the growth inhibition between these two cell types was no longer different.

Aspirin at $20 \mu \mathrm{M}$ was more potent than $100 \mu \mathrm{M}$ as an inducer of SSAT activity in colon cancer cells (Babbar
Table 2 ODC enzyme activity in $\mathrm{SSAT}^{-}$and $\mathrm{SSAT}^{+}$cells

\begin{tabular}{lllll}
\hline Time in culture (h) & 24 & 48 & 72 & 96 \\
\hline (A) & & & & \\
$\mathrm{SSAT}^{-}$ & $1.56 \pm 0.38$ & $1.58 \pm 0.23$ & $1.30 \pm 0.29$ & $1.27 \pm 0.20$ \\
$\mathrm{SSAT}^{+}$ & $3.89 \pm 0.47^{* * *}$ & $5.73 \pm 0.65^{* * *}$ & $3.35 \pm 0.20^{* * *}$ & $3.48 \pm 0.38^{* * *}$ \\
\hline Time of treatment (h) & $\mathrm{SSAT}^{-}$ & & $\mathrm{SSAT}^{+}$ & \\
\cline { 2 - 3 } \cline { 5 - 5 } & Control & Aspirin $(2 \mathrm{mM})$ & Control & Aspirin (2 mM) \\
\hline (B) & & & & \\
24 & $0.96 \pm 0.13$ & $0.18 \pm 0.08^{* * *}$ & $2.74 \pm 0.28$ & $1.70 \pm 0.25^{* *}$ \\
48 & $0.63 \pm 0.14$ & $0.39 \pm 0.14$ & $1.16 \pm 0.15$ & $0.49 \pm 0.10$ \\
\hline
\end{tabular}

Cells were seeded at a density of $2.4 \times 10^{4} / \mathrm{cm}^{2}$ in a $60 \mathrm{~mm}$ cell culture dish in duplicate. (A) The cells were harvested at a $24 \mathrm{~h}$ interval till $96 \mathrm{~h}$ in culture. (B) After $48 \mathrm{~h}$ incubation, the cells were treated with $2 \mathrm{mM}$ aspirin for 24 and $48 \mathrm{~h}$. Results shown are mean $\pm \operatorname{SEM}(n=3$, with 2 replicate per experiment). Statistical analysis was performed by 2 -way ANOVA with Bonferroni post-tests using Prism 5. ** $p<0.01$, $* * * p<0.001$

\begin{tabular}{lllllll}
\hline & $N^{1}$-ac-spd & $N^{1}$-ac-spm & Put & Spd & \multicolumn{1}{l}{ Spm } & Total \\
\hline SSAT $^{-}$ & $0.12 \pm 0.03$ & $0.03 \pm 0.01$ & $0.27 \pm 0.08$ & $3.08 \pm 0.47$ & $11.04 \pm 0.82$ & 14.54 \\
SSAT $^{+}$ & $6.34 \pm 0.74 * * *$ & $0.50 \pm 0.12 * * *$ & $1.24 \pm 0.14 * * *$ & $2.06 \pm 0.30$ & $4.75 \pm 0.66 * * *$ & 14.89 \\
\hline
\end{tabular}

Cells were seeded at a density of $2.4 \times 10^{4} / \mathrm{cm}^{2}$ on a $60 \mathrm{~mm}$ cell culture dish in duplicate, media were replaced every $48 \mathrm{~h}$. After $96 \mathrm{~h}$ incubation, polyamine fraction was extracted by perchloric acid and finally quantified by LC-MS-MS. Values are mean \pm SEM with $n=6$, two replicates per experiment. $* * * p<0.001$ 
Table 4 Effect of aspirin on the growth inhibition of $\mathrm{SSAT}^{-}$and $\mathrm{SSAT}^{+}$cells

\begin{tabular}{lcccc}
\hline Cells & \multicolumn{4}{l}{ Growth inhibition (\%) } \\
\cline { 2 - 5 } Time of treatment (h) & 24 & 48 & 72 & 96 \\
\hline SSAT $^{-}$ & 25 & 58 & 80 & 81 \\
SSAT $^{+}$ & 2 & 28 & 73 & 83 \\
\hline
\end{tabular}

Cells were seeded at a density of $2.4 \times 10^{4} / \mathrm{cm}^{2}$ in a $60 \mathrm{~mm}$ cell culture dish in duplicate. Cells were treated with aspirin after $48 \mathrm{~h}$ incubation and then harvested at $24 \mathrm{~h}$ intervals and viable cell numbers counted using Trypan blue exclusion assay. Growth inhibition (\%) was calculated as a percentage of the number of cells treated with aspirin against the number of cells of control. The growth inhibition of control cells was known as $0 \%(n=3-8$, with two replicates per experiment)

Table 5 Effect of aspirin on total polyamine concentrations

\begin{tabular}{|c|c|c|c|c|}
\hline \multirow{2}{*}{$\begin{array}{l}\text { Time of treatment } \\
\text { (h) }\end{array}$} & \multicolumn{4}{|c|}{ Total Polyamines (nmol/mg protein) } \\
\hline & 24 & 48 & 72 & 96 \\
\hline \multicolumn{5}{|l|}{$\mathrm{SSAT}^{-}$} \\
\hline Control & $17.1 \pm 3.0$ & $21.5 \pm 3.8$ & $12.6 \pm 3.3$ & $12.1 \pm 3.3$ \\
\hline Aspirin & $14.9 \pm 4.5$ & $8.9 \pm 1.3$ & $8.1 \pm 1.5$ & $8.4 \pm 2.1$ \\
\hline \multicolumn{5}{|l|}{ SSAT $^{+}$} \\
\hline Control & $24.0 \pm 6.6$ & $34.8 \pm 8.5$ & $17.8 \pm 5.0$ & $11.1 \pm 2.2$ \\
\hline Aspirin & $17.0 \pm 3.8$ & $10.7 \pm 2.4$ & $6.8 \pm 1.8$ & $7.1 \pm 2.2$ \\
\hline
\end{tabular}

Cells were seeded at a density of $2.4 \times 10^{4} / \mathrm{cm}^{2}$ on a $60 \mathrm{~mm}$ cell culture dish in duplicate. Media were replaced after the initial $24 \mathrm{~h}$ growth and then at a $48 \mathrm{~h}$ interval. Cells were treated with aspirin $(2 \mathrm{mM})$ after $48 \mathrm{~h}$ incubation and harvested at a $24 \mathrm{~h}$ interval; polyamine fraction was extracted by perchloric acid and finally quantified by LC-MS. Statistical analysis was performed using Two-way ANOVA with Bonferroni post-tests comparing with Control. $p>0.05$

\section{(A) SSAT $^{-}$}

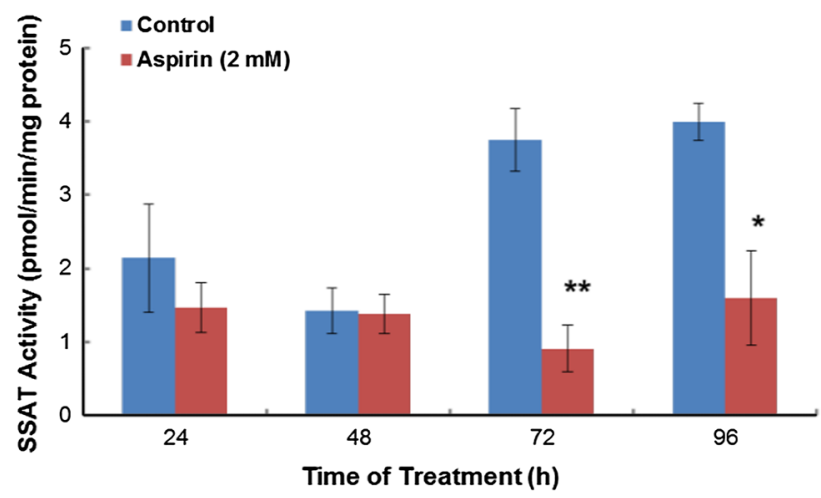

Fig. 3 Effect of aspirin on the SSAT enzyme activity. Cells were seeded at a density of $2.4 \times 10^{4} / \mathrm{cm}^{2}$ on a $60 \mathrm{~mm}$ tissue culture dish in duplicate. After $48 \mathrm{~h}$ cell growth, the medium was replaced with fresh medium containing aspirin $(2 \mathrm{mM})$. SSAT activity was assayed after $48 \mathrm{~h}$ drug exposure. a Effect of aspirin on SSAT activity in et al. 2006). This was consistent with our studies in wild type LNCaP prostate cancer cells where aspirin induced SSAT activity (around twofold but not statistically significant) in less than $48 \mathrm{~h}$ (results not shown). However, it appeared the higher aspirin concentrations the lower its potency to induce SSAT activity. As aspirin modulates the growth of prostate cancer cells we investigated whether aspirin affected SSAT activity when the enzyme activity was altered. In $\mathrm{SSAT}^{-}$cells, the Sat 1 gene expression was blocked by tetracycline, although treatment with aspirin showed a significant decrease of SSAT activity at 72 and $96 \mathrm{~h}$ (Fig. 3a). The actual non-induced SSAT enzyme activity in living cells is extremely low $(<5 \mathrm{pmol} / \mathrm{min} / \mathrm{mg}$ protein), this should not indicate a biological consequence. In $\mathrm{SSAT}^{+}$cells, treatment with aspirin suppressed the induced activity with a fivefold decrease from 24 to 96 h (Fig. 3b). Aspirin exposure decreased ODC activity in both $\mathrm{SSAT}^{+}$ and SSAT $^{-}$cells (Table 2B). Overall, the results indicate that aspirin can act either as an inducer or an inhibitor to SSAT activity, and it depends on the status of cellular SSAT activity.

Changes in both ODC and SSAT activities as a result of treatment with aspirin led to alterations in the intracellular concentrations of polyamines. Treatment with aspirin had little effect overall on the intracellular polyamine content of SSAT $^{-}$cells (Fig. 4a-e). In the $\mathrm{SSAT}^{+}$cells, however, $N^{1}$-acetylspermidine and putrescine decreased significantly and $N^{1}$-acetylspermine showed a tendency to decrease (Fig. $4 \mathrm{a}-\mathrm{e}$ ). As $N^{1}$-acetylspermidine and putrescine are the major polyamines exported from cells when cell growth is inhibited (Wallace et al. 2003) we investigated the effect of aspirin exposure on polyamine export. On the other hand, accumulation of $N^{1}$-acetylspermidine and putrescine

(B) $\mathrm{SSAT}^{+}$

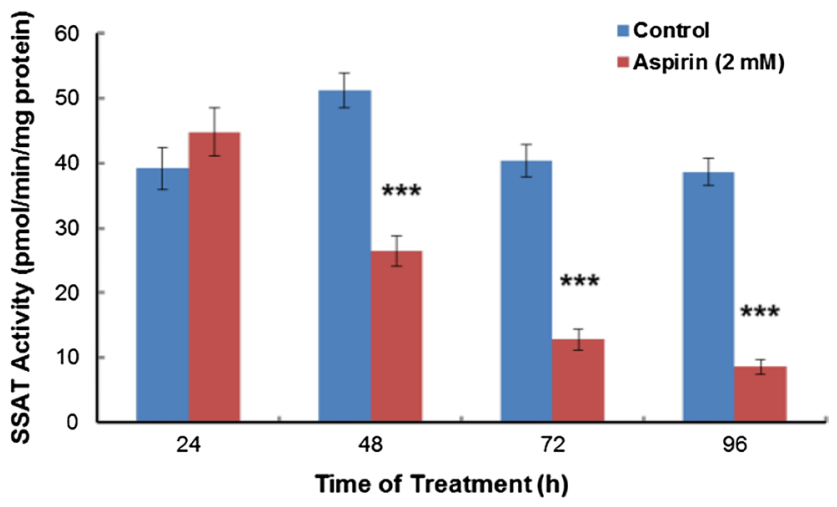

$\mathrm{SSAT}^{-}$cells. b Effect of aspirin on SSAT activity in $\mathrm{SSAT}^{+}$cells. Values were mean $\pm \operatorname{SEM}(n=3$ with 4 replicates per experiment). Statistical analysis was performed using two-way ANOVA with Bonferroni post-tests. ${ }^{*} p<0.05,{ }^{* *} p<0.01, * * * p<0.001$ 
(A) $\mathrm{N}^{1}$-acetylspermidine

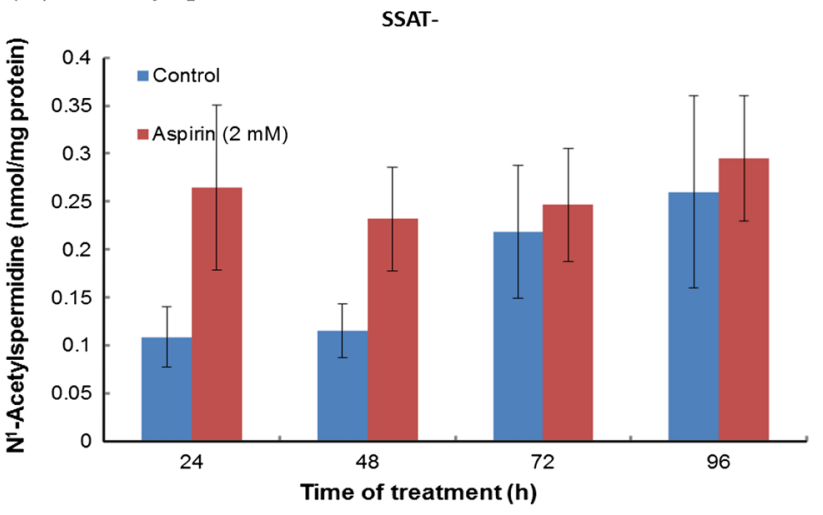

(B) $\mathrm{N}^{1}$-acetylspermine

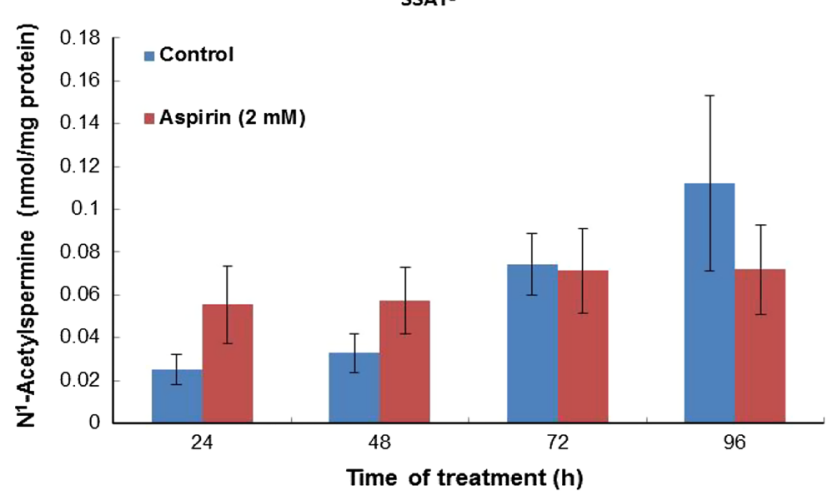

(C) Putrescine

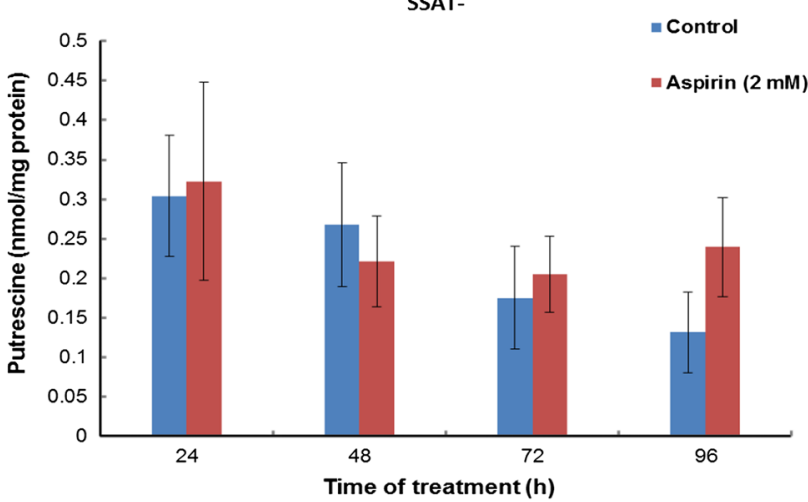

Fig. 4 Effect of aspirin on polyamine content in $\mathrm{SSAT}^{-}$and $\mathrm{SSAT}^{+}$ cells. Cells were seeded at a density of $2.4 \times 10^{4} / \mathrm{cm}^{2}$ on a $60 \mathrm{~mm}$ cell culture dish in duplicate. Media were replaced after the initial $24 \mathrm{~h}$ growth and then at a $48 \mathrm{~h}$ interval. Cells were treated with aspirin $(2 \mathrm{mM})$ after $48 \mathrm{~h}$ incubation and harvested at a $24 \mathrm{~h}$ interval; polyamine fraction was extracted by perchloric acid and finally quan-

could render the cells resistant to aspirin within $48 \mathrm{~h}$ before majority of them were exported out of the cells.

Polyamine efflux was increased significantly in $\mathrm{SSAT}^{+}$ in a time dependent manner in contrast to $\mathrm{SSAT}^{-}$cells,
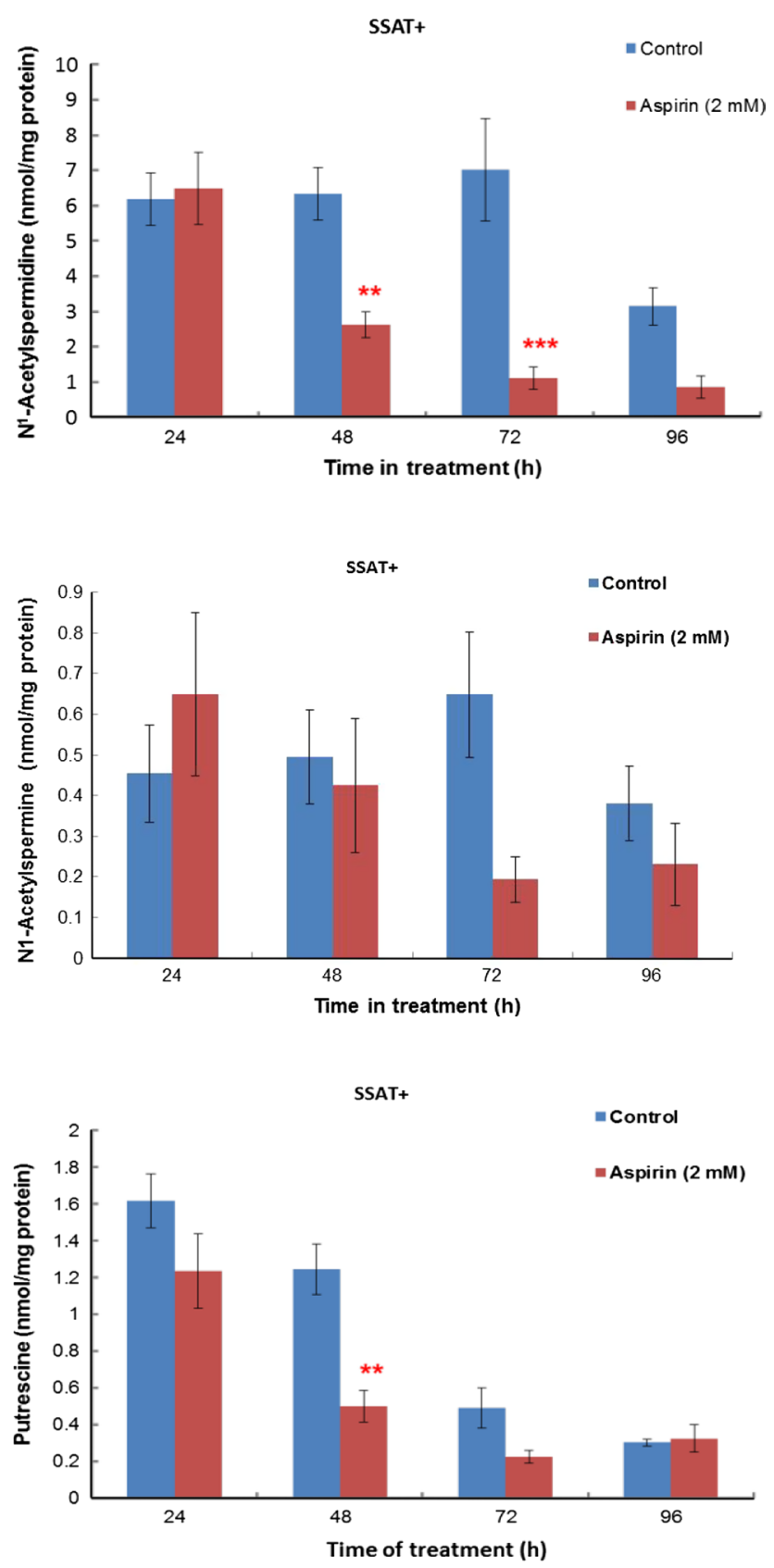

tified by LC-MS-MS. a $N^{1}$-acetylspermidine; b $N^{1}$-acetylspermine; c Putrescine; d Spermidine; e Spermine; f Total polyamines. Values are mean \pm SEM with $n=3-6$, two duplicates per experiment). Statistical analysis was performed using Two-way ANOVA with Bonferroni post-tests comparing with Control. $* p<0.05 ; * * p<0.01$; $* * * p<0.001$

indicating that polyamine export or efflux was augmented by SSAT overexpression (Fig. 5). This was not affected by aspirin treatment but aspirin did increase export in $\mathrm{SSAT}^{-}$ cells at $48 \mathrm{~h}$. 
(D) Spermidine

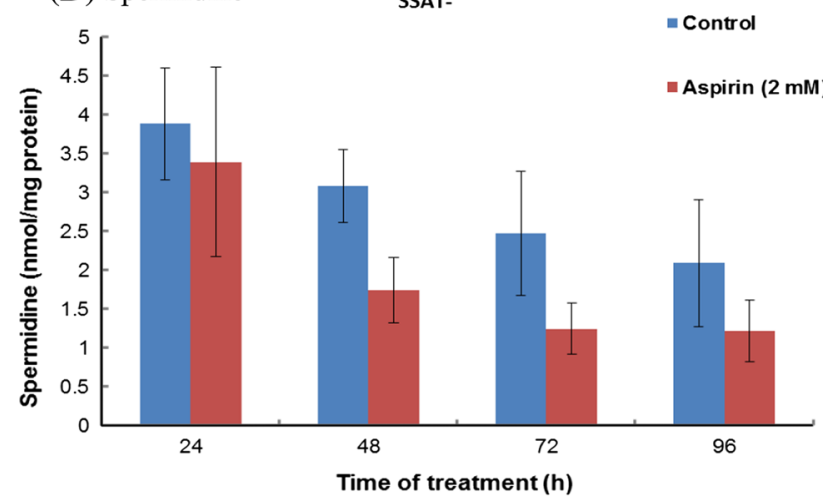

(E) Spermine

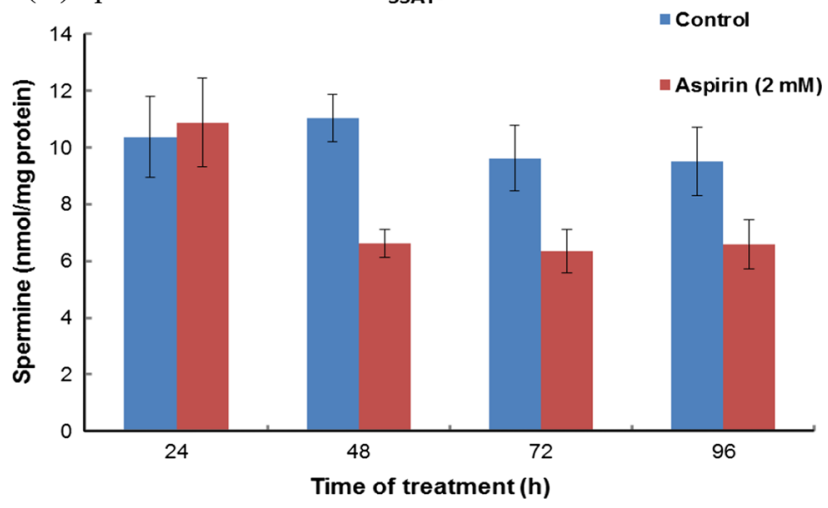

Fig. 4 continued

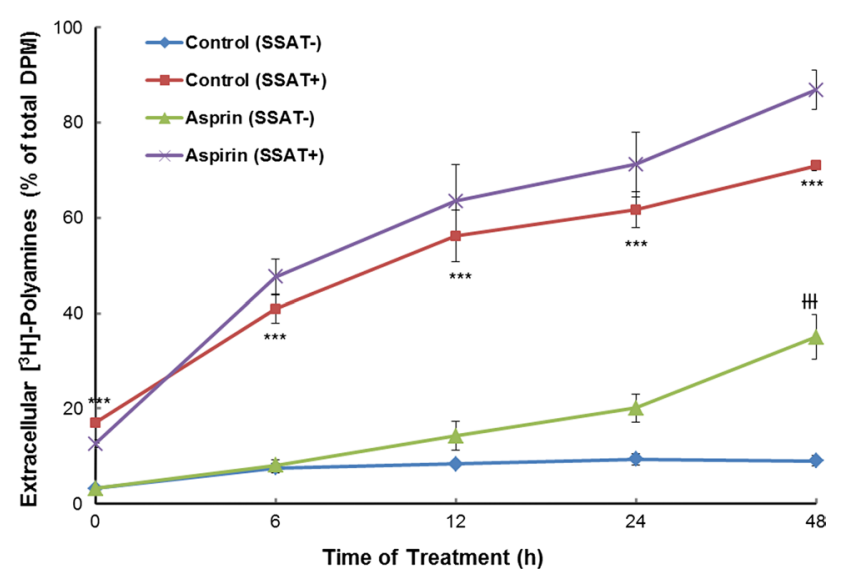

Fig. 5 Effect of aspirin on polyamine export. Cells were seeded at a density of $2.4 \times 10^{4} / \mathrm{cm}^{2}$ in a $60 \mathrm{~mm}$ cell culture dish in duplicate and incubated for $24 \mathrm{~h}$. The cells were then incubated with $\left[{ }^{3} \mathrm{H}\right]-$ putrescine for $36 \mathrm{~h}$. After removal of the $\left[{ }^{3} \mathrm{H}\right]$-putrescine for $12 \mathrm{~h}$, the cells were dosed with the $\operatorname{drug}(\mathrm{s})$ and harvested at $0,6,12,24$ and $48 \mathrm{~h}$. Radioactivity was quantified using liquid scintillation analyser. Results shown are mean $\pm \operatorname{SEM}(n=3$, with two replicates per experiment). Statistical analysis was performed by two-way ANOVA with Bonferroni post-tests using Prism5. Polyamine export was significantly higher in $\mathrm{SSAT}^{+}$than $\mathrm{SSAT}^{-}$cells without treatment. Aspirin only increased the polyamine export in $\mathrm{SSAT}^{-}$cells at $48 \mathrm{~h}$ treatment. $* * * p<0.001,{ }^{+1 \mathrm{f}} p<0.001$
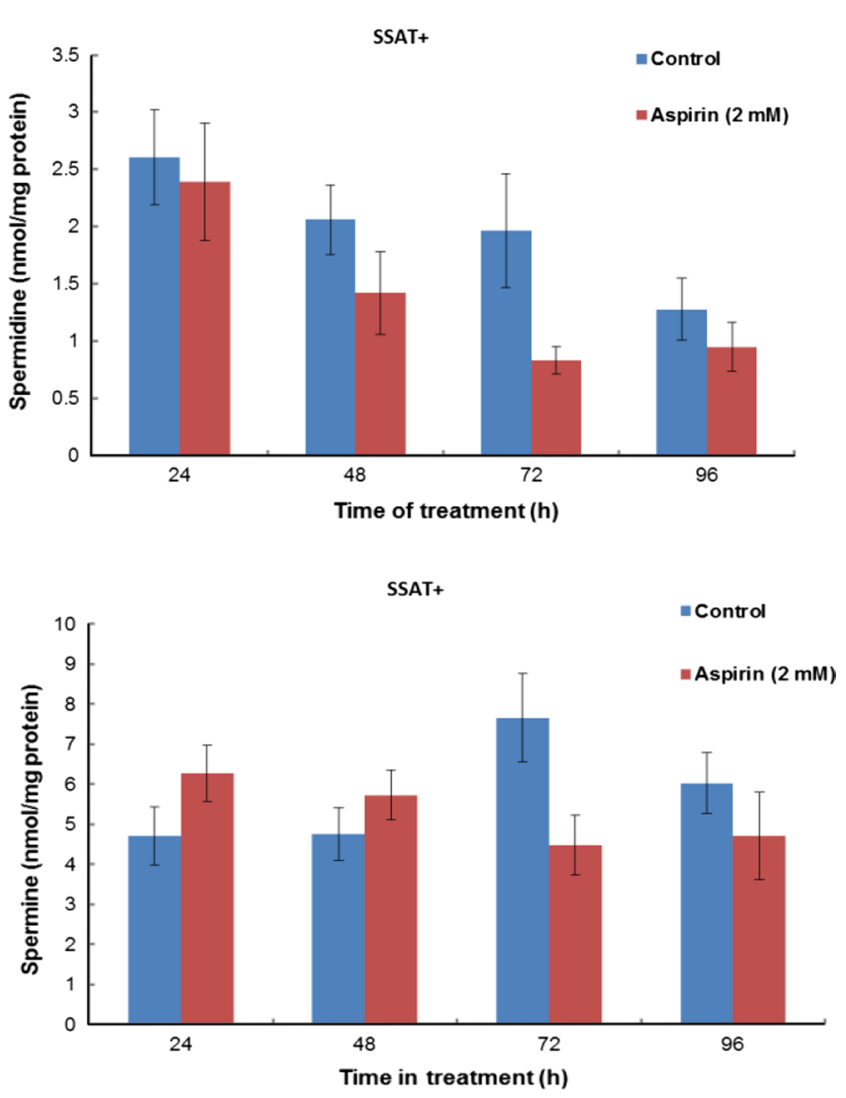

\section{Discussion}

Aspirin has been shown to be a chemopreventative agent in colorectal cancer (Thun et al. 2012) and may be useful in preventing other cancers. One mechanism by which aspirin can prevent colorectal cancer development is through inhibition of COX-2 enzyme (Sostres et al. 2014). However, additional COX-independent pathways have been discovered in a number of other studies (Chan et al. 2007; Hubner et al. 2008; Babbar et al. 2006). In our laboratory, NSAIDs such as naproxen have been shown to induce SSAT and cause cytotoxicity in HCT-115 colorectal cancer cells with no COX activity. This indicates a link between SSAT activity and inhibition of cancer cell growth, i.e. SSAT induction leading to depletion of intracellular polyamine pools and decreased cell growth (Hughes et al. 2012). Similarly, aspirin induced SSAT activity in Caco-2 cells that ultimately led to a decrease in cellular polyamine content. Thus, activation of SSAT by aspirin may play a role in chemoprevention in colon carcinogenesis by decreasing the content of polyamine growth factors (Babbar et al. 2006). In this study, overexpression of SSAT appeared to result in a rise in total polyamine content instead of polyamine depletion in $\mathrm{SSAT}^{+}$cells. This was consistent with the study by Kee 
et al. (2004). These results suggest that depletion of intracellular polyamine pools by SSAT induction can be cell type dependent.

There is a lack of clinical evidence that aspirin can prevent prostate cancer development although some studies indicate that there is an inverse association of aspirin use and the development of prostate cancer (Nelson and Harris 2000). In the present study, induced SSAT activity not only inhibited the cell proliferation but desensitised the cells to aspirin. Thus, it provides in vitro evidence that sensitivity of human prostate cancer cells to NSAIDs (aspirin) is associated with the status of cellular SSAT activity.

SSAT overexpression was not only growth inhibitory, but also resulted in resistance to aspirin. A shift from resistance to sensitivity of the cells was simultaneously concomitant with a decrease of induced SSAT activity in response to aspirin. To our knowledge, this is the first time that SSAT activity was found to be associated with aspirin resistance or sensitivity in human tumour cells in vitro. Thus, the efficacy of aspirin in cancer prevention is likely to be associated with inherent cellular SSAT activity. SSAT mRNA was found increased in cancerous human prostate specimens compared with their benign counterparts. In addition, increased SSAT mRNA was more observed in Gleason score 8 than score 2 in these specimens (Bettuzzi et al. 2000). Thereby, cancer cells with high natural SSAT activity might be expected to be more resistant to NSAIDs than cells with low SSAT activity. Our results indicate that the cell resistance to aspirin may occur at an early stage in the treatment and it would reduce with time until SSAT activity is lowered to normal level.

Aspirin tends to induce to SSAT gene expression and activity only if cellular SSAT activity is at normal or low level. When SSAT activity is pre-induced, aspirin, especially at a higher concentration $(2 \mathrm{mM})$, inhibits the SSAT activity. This suggests that whether aspirin is an inducer or inhibitor of SSAT, depends on status of cellular SSAT.

The SSAT reduction by aspirin causing growth inhibition must lead to alterations of intracellular polyamine concentrations since SSAT is a key regulator in polyamine metabolism. As a result of considerable accumulation of intracellular $N^{1}$-acetylpolyamines, mainly $N^{1}$-acetylspermidine and putrescine, the total polyamine content in $\mathrm{SSAT}^{+}$cells tend to rise. It is thought that the accumulation of these polyamines not only inhibits the cell growth but also renders aspirin resistance the cells. A typical phenotype (hair loss and wrinkled skin) of SSAT transgenic mice is believed to be due to the massive accumulation of putrescine in the skin (Pietilä et al. 1997), thus putrescine accumulation may be toxic. On the other hand, low concentrations of spermidine and spermine may also prevent the cells from proliferating and differentiating, since spermidine and spermine are known to be involved in both processes. Our results further confirmed the speculation that either an accumulation or a depletion of intracellular polyamines could be detrimental to the cell. Furthermore, polyamine export is an important part of the regulation of intracellular polyamine concentrations, and this process is also closely associated with SSAT activity. Thereby, the slow proliferation rate of $\mathrm{SSAT}^{+}$cells is likely to be linked to the altered balance in the intracellular polyamine content.

The polyamine metabolic pathway has been recognised as a target for cancer therapy and alternations in polyamine content affect cell proliferation. Based on our findings, aspirin is expected to lower SSAT activity in early prostate tumours, therefore enhancing the sensitivity of the tumour cells to the drug and finally preventing tumour development via changing cellular polyamine content. We demonstrated that SSAT acts as a determinant on the chemopreventative effect of aspirin in prostate tumour cells. This determination is closely associated with concentrations of each of the intracellular polyamines.

In summary, the present study suggests that the mechanisms by which aspirin prevents the growth of cancer cells may involve polyamine metabolism as was found in colon cancer cells and may be independent of COX pathways. Modification of intracellular polyamine concentrations via changes in SSAT activity is associated with the rate of prostate cancer cell proliferation but also with the sensitivity of the cells to aspirin. This is the first time this link has been shown. In the use of aspirin to prevent the growth of prostate cancer cells, intracellular polyamine content may play an important role in determining the sensitivity of the cells and SSAT may be a both a target for aspirin and a key regulator of drug response.

Acknowledgments We thank NHS Grampian for financial support of this work.

\section{Compliance with ethical standards}

Conflict of interest There are no conflicts of interest for any of the authors.

Open Access This article is distributed under the terms of the Creative Commons Attribution 4.0 International License (http://creativecommons.org/licenses/by/4.0/), which permits unrestricted use, distribution, and reproduction in any medium, provided you give appropriate credit to the original author(s) and the source, provide a link to the Creative Commons license, and indicate if changes were made.

\section{References}

Babbar N, Gerner EW, Casero RA Jr (2006) Induction of spermidine/ spermine $N^{1}$-acetyltransferase (SSAT) by aspirin in caco- 2 colon cancer cells. Biochem J 394:317-324. doi:10.1042/BJ20051298 
Bettuzzi S, Davalli P, Astancolle S, Carani C, Madeo B, Tampieri A, Corti A. (2000) Tumor progression is accompanied by significant changes in the levels of expression of polyamine metabolism regulatory genes and clusterin (sulfated glycoprotein 2) in human prostate cancer specimens. Cancer Res 60:28-34 (PubMed ID: 10646846)

Bosetti C, Gallus S, La Vecchia C (2009) Aspirin and cancer risk: a summary review to 2007. Recent Results Cancer Res 181:231251. doi:10.1007/978-3-540-69297-3_22

Chan AT, Ogino S, Fuchs CS (2007) Aspirin and the risk of colorectal cancer in relation to the expression of COX-2. N Engl J Med 356:2131-2142. doi:10.1056/NEJMoa067208

Criss WE (2003) A review of polyamines and cancer. Turkish J Med Sci 33:195-206

Dozmorov MG, Hurst RE. Culkin DJ, Kropp BP, Frank MB, Osban J, Penning TM, Lin HK (2009) Prostate 69:1077-1090. doi:10.1002/pros.20960

Globocan 2008: Cancer incidence and mortality worldwide. International Agency for Research on Cancer, WHO. Available from: http://www.iarc.fr/en/media-centre/iarcnews/2010/globocan2008.php

Hsu AL, Ching TT, Wang DS, Song X, Rangnekar VM, Chen CS (2000) The cyclooxygenase-2 inhibitor celecoxib induces apoptosis by blocking Akt activation in human prostate cancer cells independently of Bcl-2. J Biol Chem 275:11397-11403. doi:10.1074/jbc.275.15.11397

Hubner RA, Muir KR, Liu JF, Logan RFA, Grainge MJ, Houlston RS, Members of the UKCAP Consortium (2008) Ornithine decarboxylase G316A genotype is prognostic for colorectal adenoma recurrence and predicts efficacy of aspirin chemoprevention. Clin Cancer Res 14:2303-2309. doi:10.1158/1078-0432. CCR-07-4599

Hughes A, Saunders FR, Wallace HM (2012) Naproxen causes cytotoxicity and induces changes in polyamine metabolism independent of cyclo-oxygenase expression. Toxicol Res 1:108-115. doi:10.1039/C2TX20018J

Isaacs W, De Marzo A, Nelson WG (2002) Focus on prostate cancer. Cancer Cell 2:113-116. doi:10.1016/S1535-6108(02)00103-4

Kee K, Vujcic S, Merali S, Diegelman P, Kisiel N, Powell CT, Kramer DL, Porter CW (2004) Metabolic and antiproliferative consequences of activated polyamine catabolism in $\mathrm{LNCaP}$ prostate carcinoma cells. J Biol Chem 279:27050-27058. doi:10.1074/ jbc.M403323200

Khandrika L, Kumar B, Koul S, Maroni P, Koul HK (2009) Oxidative stress in prostate cancer. Cancer Lett 282:125-136. doi:10.1016/j.canlet.2008.12.011

Kramer DL, Diegelman P, Jell J, Vujcic S, Merali S, Porter CW (2008) Polyamine acetylation modulates polyamine metabolic flux, a prelude to broader metabolic consequences. J Biol Chem 283:4241-4251. doi:10.1074/jbc.M706806200

Lin DW, Nelson PS (2003) The role of cyclooxygenase-2 inhibition for the prevention and treatment of prostate carcinoma. Clin Prost Cancer 2:119-126. doi:10.3816/CGC.2003.n.020

Liu XH, Tao S, Kirschenbaum A, Levine AC (1998) N398, a selective cyclooxygenase-2 inhibitor, induces apoptosis and down-regulates bcl-2 expression in LNCaP cells. Cancer Res 58:4245-4249

Lowry OH, Rosebrough NJ, Farr AL, Randall RJ (1951) Protein measurement with the Folin phenol reagent. J Biol Chem 193:265-275

Mahmud S, Franco E, Aprikian A (2004) Prostate cancer and use of nonsteroidal anti-inflammatory drugs: systematic review and meta-analysis. $\mathrm{Br} \mathrm{J}$ Cancer 90:93-99. doi:10.1038/ sj.bjc. 6601416

Mandal S, Mandal A, Johansson HE, Orjalo AV, Park MH (2013) Depletion of cellular polyamines, spermidine and spermine, causes a total arrest in translation and growth in mammalian cells. Proc Natl Acad Sci 110:2169-2174. doi:10.1073/pnas.1219002110

Michael JT, Eric JJ, Carlo P (2012) The role of aspirin in cancer prevention. Nature reviews: Clinical Oncology 9:259-267. doi:10.1038/nrclinonc.2011.199

Nelson JE, Harris RE (2000) Inverse association of prostate cancer and non-steroidal anti-inflammatory drugs (NSAIDs): results of a case-control study. Oncol Rep 7:169-239. doi:10.3892/ or.7.1.169

Pegg AE (2009) Mammalian polyamine metabolism and function. IUBMB Life 61:880-894. doi:10.1002/iub.230

Pietilä M, Alhonen L, Halmekytö M, Kanter P, Jänne J, Porter CW (1997) Activation of polyamine catabolism profoundly alters tissue polyamine pools and affects hair growth and female fertility in transgenic mice overexpressing spermidine/spermine $N^{1}$-acetyltransferase. J Biol Chem 272:18746-18751. doi:10.1074/jbc.272.30.18746

Rothwell PM, Fowkes FGR, Belch JFF, Ogawa H, Warlow CP, Meade TW (2011) Effect of daily aspirin on long-term risk of death due to cancer: analysis of individual patient data from randomised trials. Lancet 377:31-41. doi:10.1016/ S0140-6736(10)62110-1

Shappell NW, Fogel-Petrovic MF, Porter CW (1993) Regulation of spermidine/spermine $N^{1}$-acetyltransferase by intracellular polyamine pools: evidence for a functional role in polyamine homeostasis. FEBS Lett 321:179-183. doi:10.1016/0014-5793(93)80103-2

Sostres C, Gargallo CJ, Lanas A (2014) Aspirin, cyclooxygenase inhibition and colorectal cancer. World J Gastroin Pharmacol Therap 5:40-49. doi:10.4292/wjgpt.v5.i1.40

Tabib A (1998) Determination of ornithine decarboxylase activity using $\left[{ }^{3} \mathrm{H}\right]$ ornithine. Methods Mole Biol Polyam Prot 79:33-39. doi:10.1385/0-89603-448-8:33

Thun MJ, Jacobs EJ, Patrono C (2012) The role of aspirin in cancer prevention. Nature Rev Clin Oncol 9:259-267. doi:10.1038/ nrclinonc.2011.199

Vujcic S, Halmekyto M, Diegelman P, Gan G, Kramer DL, Janne J, Porter CW (2000) Effects of conditional overexpression of spermidine/spermine $N^{1}$-acetyltransferase on polyamine pool dynamics, cell growth, and sensitivity to polyamine analogs. J Biol Chem 275:38319-38328. doi:10.1074/jbc.M003270200

Wallace HM (2000) The physiological role of the polyamines. Eur J Clin Invest 30:1-3. doi:10.1046/j.1365-2362.2000.00585.x

Wallace HM, Evans DM (1998) Measurement of spermidine/spermine $N^{1}$-acetyltransferase activity. Methods Mol Biol Polyam Prot 79:59-68. Edited by Morgan DM. Totowa, New Jersey: Humana Press Inc. doi:10.1385/0-89603-448-8:59

Wallace HM, Hughes A (2006) Protective effect of polyamines on NSAID-induced injury and apoptosis. Polyamine Cell Signaling. Physiology, Pharmacology, and Cancer Research. Edited by Wang JY, Casero Jr RA. 273-274. Totowa, New Jersey: Human press Inc

Wallace HM, Mackarel J (1998) Regulation of polyamine acetylation and efflux in human cancer cells. Biochem Soc Trans 26:571575. doi:10.1042/bst0260571

Wallace HM, Fraser AV, Hughes A (2003) A perspective of polyamine metabolism. Biochem J 376:1-14. doi:10.1042/BJ20031327 